\title{
Water table fluctuation method to estimate the recharge of the free aquifer in the guariroba river basin, Campo Grande - MS
}

\author{
Daniel Russi '; Giancarlo Lastoria "; Guilherme Henrique Cavazzana III \\ Sandra Garcia Gabas Iv; Andressa Oliva v
}

\begin{abstract}
The Guariroba river basin was decreed as an Environmental Protection Area (EPA), and with a surface of $360 \mathrm{~km}^{2}$ it is of great importance to the municipality of Campo Grande because it supports almost half of the water supply system of the latter. The surface of the basin is predominantly covered by Cretaceous sediments of the Caiuá Group, which constitutes the free aquifer known as the Bauru Aquifer System (BAS). Recent studies have confirmed the contribution of the BAS in the maintenance of the base flow of surface drainage. Therefore, the quantification of groundwater recharge (GWR) becomes fundamental. This work used the water table fluctuation (WTF) method, based on variations in the piezometric surface-water measurement, to estimate the GWR of the basin. From Mar 2015-Feb 2017, monthly variations of the static level were registered in 13 tubular wells located in the Guariroba EPA. Considering a $1480 \mathrm{~mm}$ annual precipitation, the estimated average GWR was 356 $\mathrm{mm} \cdot \mathrm{year}^{-1}$, varying between 210-694 mm.year ${ }^{-1}$. Despite considering a lower value of the effective porosity parameter $(S y=0.1)$ than the one suggested for the BAS, the estimated average GWR-to-precipitation ratio (24\%) was more than double that the one adopted by the state environmental agency (10\%).
\end{abstract}

Keywords: Bauru Aquifer System Recharge; groundwater table fluctuation; watershed

\footnotetext{
${ }^{1}$ Federal University of Mato Grosso do Sul - UFMS; Faculty of Engineering, Architecture and Urbanism and Geography -, Campo Grande - MS., Brazil. - https://orcid.org/0000-0003-2066-0404 - Daniel.russi@gmail.com

${ }^{2}$ Federal University of Mato Grosso do Sul - UFMS; Faculty of Engineering, Architecture and Urbanism and Geography - Campo Grande - MS., Brazil. -: g.lastoria@ufms.br

${ }^{3}$ Federal University of Mato Grosso do Sul - UFMS; Faculty of Engineering, Architecture and Urbanism and Geography - Campo Grande - MS., Brazil. - https://orcid.org/0000-0001-6878-3687 - cavazzana.ea@gmail.com

${ }^{4}$ Federal University of Mato Grosso do Sul - UFMS; Faculty of Engineering, Architecture and Urbanism and Geography - Campo Grande - MS., Brazil. - https://orcid.org/0000-0002-1027-0288 - sandra.gabas@ufms.br

5 Federal University of Soulth of Bahia - UFSB; Sosígenes Costa Camp; University City, Porto Seguro - BA., Brazil. https://orcid.org/0000-0002-3068-9828 - aoliva@ufsb.edu.br
} 


\section{INTRODUCTION}

The basin of the Guariroba river is located in a rural area of the federal district of Mato Grosso do Sul, on the northeastern border of its capital (the municipality of Campo Grande). A dam constructed at the mouth of the basin in 1982 provides a flow rate of $1.4 \mathrm{~m}^{3} \cdot \mathrm{s}^{-1}$, approximately half the Campo Grande water supply system, which has a population of over 800,000 inhabitants. Because of its importance for the water supply system of Campo Grande, the hydrographic unit of Guariroba river was declared an Environmental Protection Area (EPA) by the Municipal Administration, by decree, in 1995.

The land in the Guariroba EPA is being used predominantly for intensive livestock activities, and the increasing replacement of native forests by eucalyptus forest. Most of the Guariroba river basin is covered by Cretaceous sediments from the Caiuá Group, which constitute the free aquifer called the Bauru Aquifer System (BAS). Water flow rates measured in the Guariroba river fluctuate between $4.8-7.5 \mathrm{~m}^{3} \cdot \mathrm{s}^{-1}$,

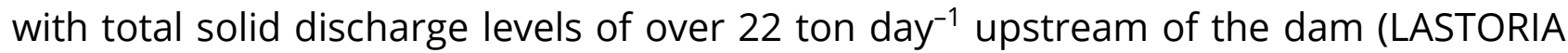
et al., 2017).

In recent years, due to the erosive potential of the Bauru/Caiuá Groups in the Guariroba river basin, actions are being taken to reduce the input of sediments to the drainage system and dam, including the support of the National Water Agency, through the Payment for Environmental Services program.

Cavazzana et al. (2019) developed a potentiometric map using data from more than a dozen tubular wells drilled in the BAS. The preliminary hydrogeological analysis performed by Cavazzana et al. (2019) showed that the BAS contributes significantly to maintain the base flow of the Guariroba river basin. Therefore, quantitative knowledge of the main free aquifer in the basin is essential. It is important to note that in addition to maintaining the base flow of the site superficial drainage, the underwater recharge variable has important practical implications because the state environmental agency sets the volume of groundwater granted for exploitation from an estimation of the water infiltration from annual precipitation. 
The objective of this work was to estimate the groundwater recharge of the Guariroba river basin. Although there are several methodologies and tools to estimate the groundwater recharge of an aquifer, this work focused on the Water table Fluctuation (WTF) method, based on the analysis of water-level fluctuations in observation wells (Healy and Cook, 2002). Data on the hydrography, climate, geology and geomorphology, hydrogeology, and geophysical characterization of the Guariroba APA was collected to estimate the groundwater recharge of the Guariroba river basin and to evaluate the aquifer in the basin.

\section{MATERIALS AND METHODS}

\subsection{Location of the study area, climate, and hydrography}

Figure 1 shows a map of the study area. The Guariroba EPA covers a total surface of $360 \mathrm{~km}^{2}$; according to the Köppen model, its climate is classified as Aw-type, i.e., hot and humid, predominantly with summer rains and winter drought. The annual average temperature is $23.2^{\circ} \mathrm{C}$, with variation throughout the year from $5.7-37.5^{\circ} \mathrm{C}$. The average total annual precipitation varies from 1400-1500 mm (CAMPO GRANDE, 2008). The Guariroba river is included in the Planning and Management Unit of Pardo river, an affluent of the Botas river, which is also part of the Paraná River Basin (SEMAC, 2010).

\subsection{Geology and geomorphology}

Detailed scale geological characterization for the Guariroba EPA is scarce. Only one single geological profile of a $165 \mathrm{~m}$ deep tubular well, drilled in the Soberana Farm (PO-04), is available. In the lithostratigraphic column of this well, a sequence of sandy-clayey sediments is reported, up to $114 \mathrm{~m}$, with cream to light brown silt and clay interleaves. From 114-146 m, a sandy homogeneous layer exists with medium to fine granulometry. This sedimentary package corresponds to the Caiuá Group, which 
emerges over $90 \%$ of the Guariroba EPA. From 146-165 m, the basalts of the Serra Geral Formation (SGSA) appear, more fractured and altered in the superior contact, becoming massive and unchanged rock in the final part of the well. On the surface, the basic magmatic occurs in a narrow strip, notably along the main drainage of the basin. Figure 2-a shows the geology of the area under study, and Figure 2-b illustrates the hypsometric variations between 440-640 m, with a slight slope in the topography $(4-8 \%)$.

Figure 1 - Location of Guariroba EPA, in Campo Grande-MS (LASTORIA et al., 2018). $(\bullet)$ wells; $(O)$ rainfall gauging stations; $(\triangle)$ liningraph

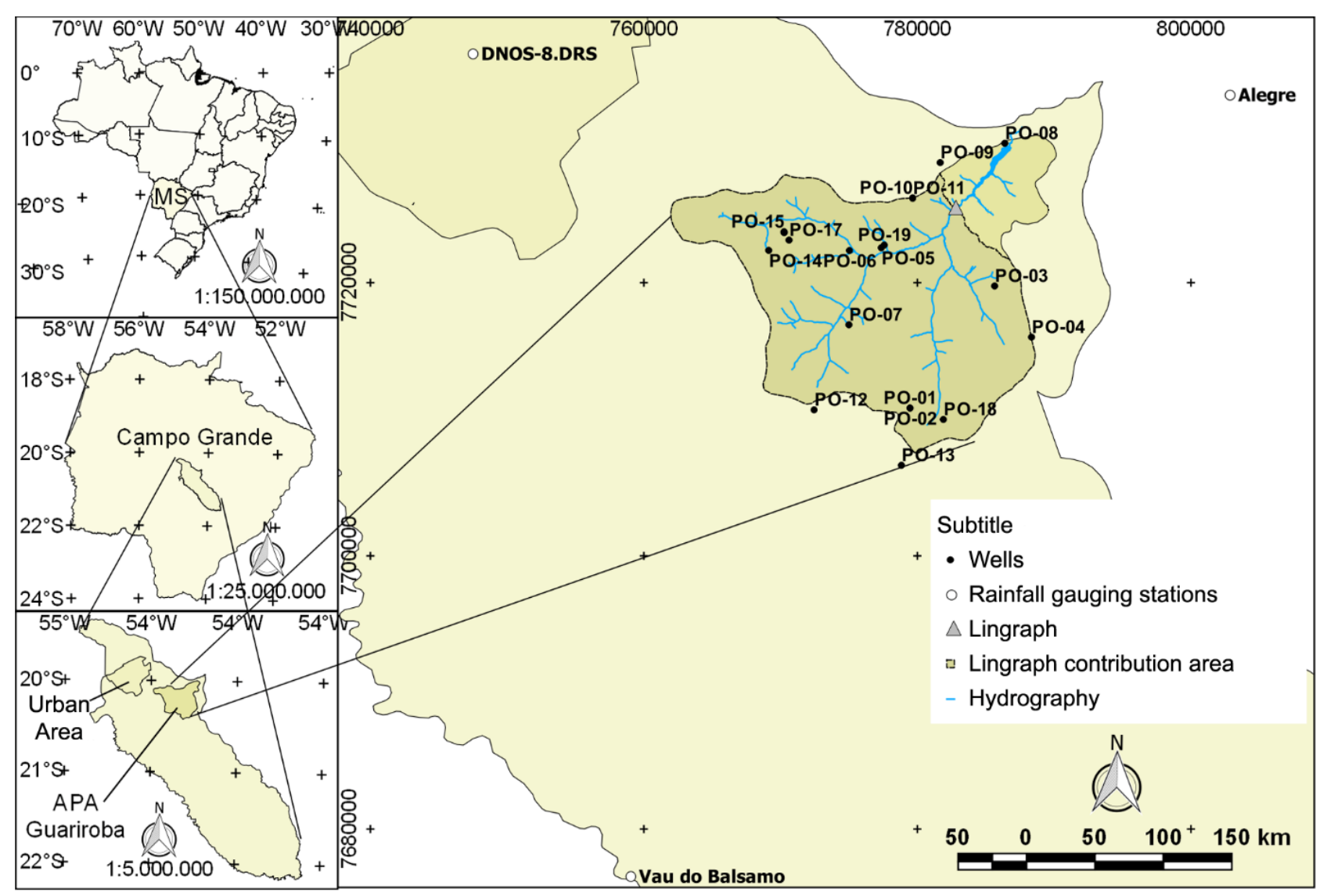

\subsection{Hydrogeology and data collection}

The State Water Resources Plan/MS (SEMAC, 2010) identifies eight aquifer systems in Mato Grosso do Sul. The area study (Guariroba EPA) is in the domain of the hydrogeological unit defined as BAS, a free aquifer of sedimentary nature with 
intergranular porosity. According to the geological map of the state (CPRM, 2006), the BAS hydrogeological unit belongs to the Caiuá Group.

The basal sequence of the BAS hydrogeological unit, which covers local basaltic spills, is described as a riverine deposition environment. The lithological variability, typical of this environment, is clearly distinguished on its surface, both in terms of color (cream, reddish, gray) and texture (sands with medium to fine granulometry, sometimes clayey, moderately selected). While measuring the hydraulic conductivity (K) of the unsaturated zone, Casadei (2016) found the predominant soil to be of medium texture, ranging from sandy to very clayey, in 22 points, tested at depth of 1 $\mathrm{m}$. The K values reported by Casadei (2016) were between $0.5 \mathrm{~m} \cdot \mathrm{day}^{-1}$ (moderate) and $16.1 \mathrm{~m} \cdot \mathrm{day}^{-1}$ (very fast).

Figure 2 - Figure 2(a) Geology and figure 2(b) Hypsometry of the area under study with the location of the monitored tubular wells (CAVAZZANA et al., 2019).

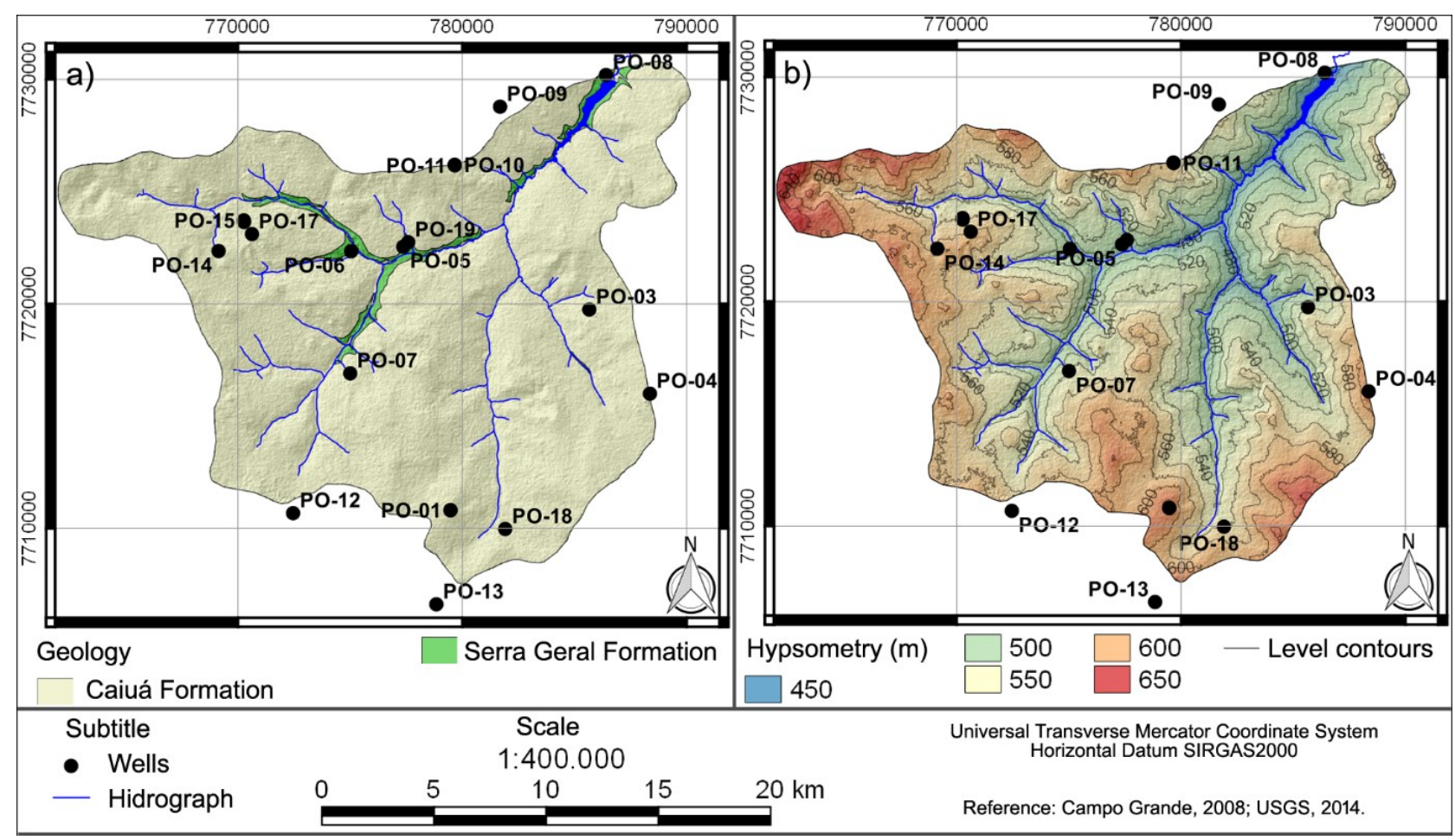

Despite its abundant natural surface drainage network (Figure 2), several tubular wells, irregularly distributed, were constructed in the Guariroba EPA. Only one of the existing wells had a hydrogeological profile. In the 13 tubular wells whose 
owners allowed their use for static level monitoring, a weldable PVC guide-tube was installed to introduce an electronic level meter with centimeter precision. A collaboration protocol was also established with all the well users to shut down the pumps at the end of the day before the measurement, allowing a minimum period of $12 \mathrm{~h}$ to allow recovery of the static level. The measurements were carried out monthly for two years, from March 2015 to February 2017.

\subsection{Geophysical characterization of Guariroba EPA}

Due to the irregular distribution of wells in the study area and the high cost of constructing new piezometers that could fill the space lagoons, a preliminary geophysical characterization was performed through an agreement between the Federal University of Mato Grosso do Sul-UFMS and the LEBAC Laboratory from the Sao Paulo State University-UNESP/Rio Claro.

Six 2D Electrical Images (2DEI) and eight Vertical Electrical Surveys (VES) were performed to cover the entire Guariroba water basin area, connect with Caiuá/Serra Geral, and reach the depth of the water table at these points. VES profiles show this information clearly. The results of the geophysical study of the 2DEI, as exemplified in Figure 3, show the vertical and horizontal variation of apparent resistivity, highlighting the heterogeneity of the Caiuá Group in the study area.

Figure 3 - L1 section of modelled electrical imaging, performed at an elevation of 622 $\mathrm{m}, 820 \mathrm{~m}$ long.

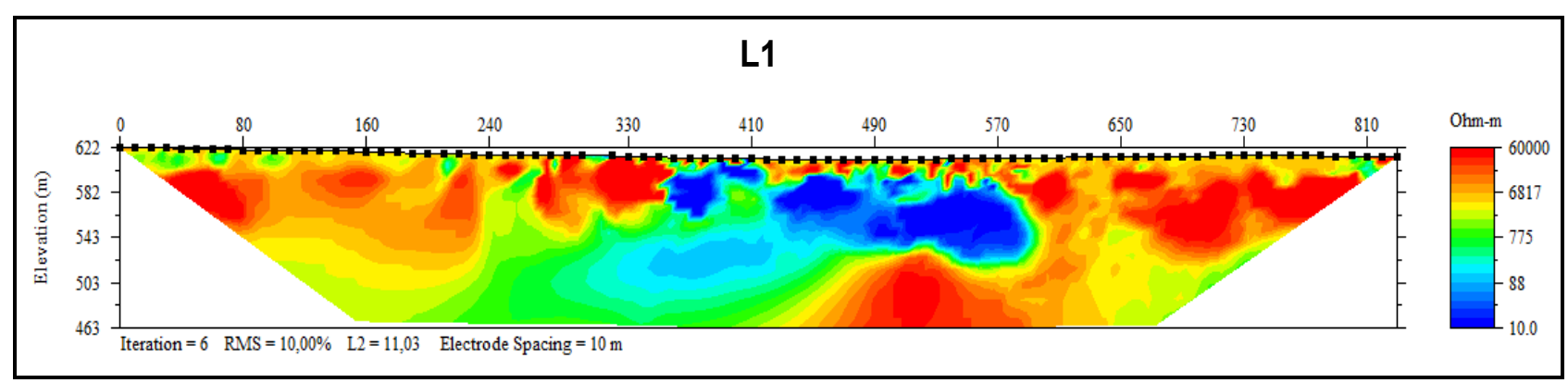


Based on the results of 2DEI and VES, it was possible to determine - for the entire Guariroba EPA area-that the thickness of the Caiuá Group varied, at the investigated points, from 64.5-180 m, and that the water table level was between 562 m (LASTORIA et al., 2018).

\subsection{Calculation of recharge by floating the piezometric surface}

The Water-Table Fluctuation (WTF) method provides an estimate of groundwater recharge by analysis of water level fluctuations in observation wells. The method is based on the assumption that an increase in the water table elevation is related solely to the rise of the static level $(\mathrm{SL})$, as a function of the infiltration and percolation of some precipitation, at a specific porosity condition characteristic of each aquifer. Therefore, groundwater recharge corresponds to a renewable resource.

Groundwater recharge (GWR) is calculated by Equation 1, which correlates the variation of $S L(\Delta h)$, over a period of time $(\Delta t)$, with a specific yield (Sy). Due to its practicality, the WTF method is one of the most widely used methods to estimate GWR (CHUNG et al., 2016).

$$
\mathrm{GWR}=\mathrm{Sy} \cdot \frac{\Delta \mathrm{h}}{\Delta \mathrm{t}}
$$

Monitoring the variation of SL throughout the year requires a simple measurement methodology. However, Sy, which physically represents the amount of water infiltrated through the layer by the action of gravity, is more difficult to obtain. This parameter, which is equivalent to the effective porosity, or even to the storage coefficient, depends on the particle size characteristics of the sedimentary aquifer and can be obtained indirectly through the ternary diagram of textural classification, proposed by Johnson (1963) (Figure 4). 
Figure 4 - Diagram of textural classification and specific yield, in relation to the particle size composition (adapted from JOHNSON, 1963).

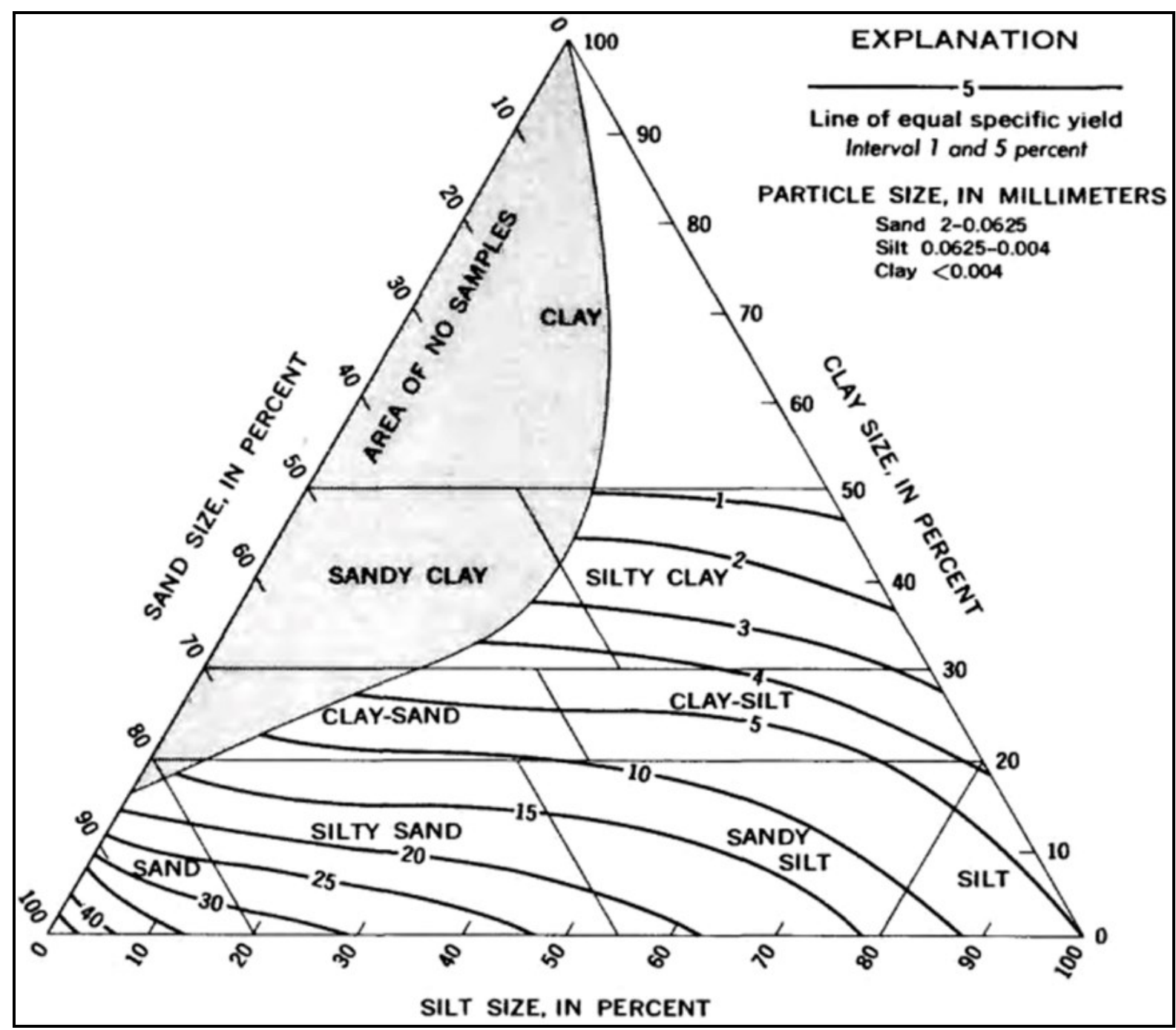

Even though BAS is considered a homogeneous aquifer, the 2DEI geophysical study performed in the Guariroba EPA confirmed the horizontal and vertical variability of its composition, directly implying changes in Sy values. This fact may explain the different recharge values, determined from different observation wells in the same aquifer, under similar precipitation conditions. Mancuso and Campos (2005) report Sy values between $10-15 \%$ for the BAS in the State of São Paulo. For the State of Mato Grosso do Sul, TAHAL/SANESUL (1998) used BAS effective porosity values between 10$15 \%$. 


\section{RESULTS AND DISCUSSION}

Figure 5 shows the graphic model used to obtain the $\Delta \mathrm{h}$ values by correlating the SL measured monthly in the 13 monitoring wells in the Guariroba EPA from March 2015 to February 2017. Note the extrapolation of the hydrograph from the linear regression curve until the end of the SL rise period. An oscillation of $\Delta h$ values, less than $3 \mathrm{~m}$ (Table 1), was observed, except for PO-08-which is in the basalt upwelling area in the SASG, unlike the other wells in the BAS. The small SL variation in this observation interval may be associated with the occurrence of two very rainy years, with an annual precipitation volume of $1,480 \mathrm{~mm}$.

Figure 5 - Graphic model of piezometric surface variations of monitored wells (SL), the extrapolated linear regression of the hydrograph and the respective mathematical equation.

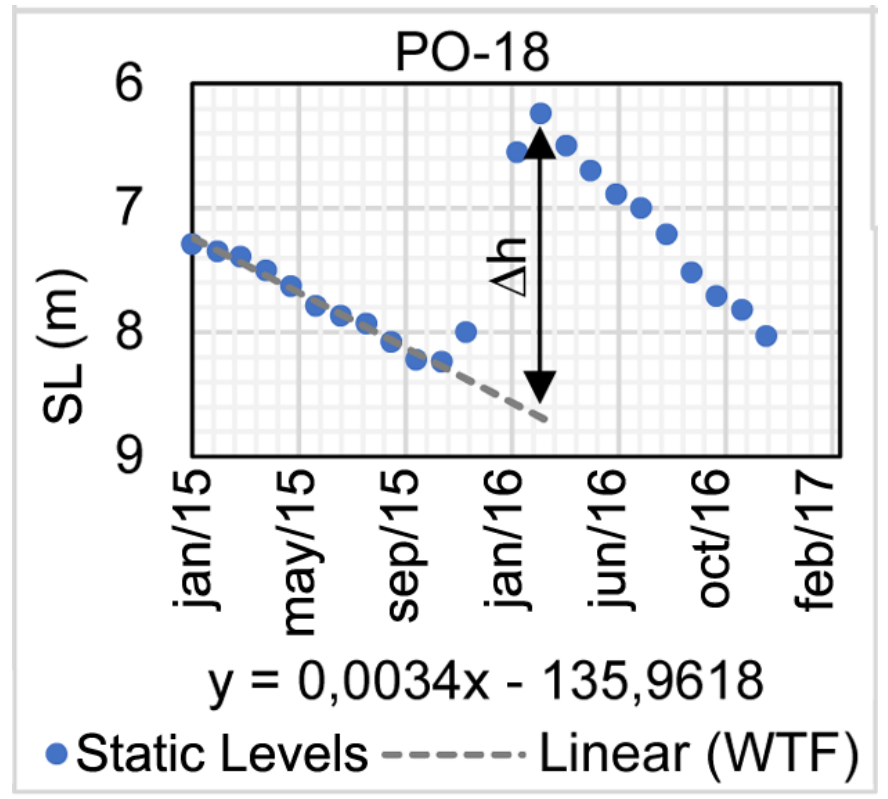

It is worth noting that the occurrence of a period of higher precipitation implies greater availability of water for infiltration and, consequently, a higher GWR. Conversely, this condition does not lead to a more pronounced SL lowering, which is characteristic of a prolonged drought period. Thus, the value of $\Delta \mathrm{h}-$ which has a direct influence on GWR (Eqn. 1)-is lower. Another component of Eqn. 1 that also has 
an important influence on GWR is the Sy. This work adopted a conservative scenario to calculate the recharge using the minimum effective porosity value (10\%) pointed out by TAHAL/SANESUL (1998) for the BAS.

Table 1-Values of $\Delta h, \Delta t$ and minimum groundwater recharge (GWR), calculated by the WTF method, per monitored well, as a function of the adopted specific yield (Sy) and aquifer groundwater recharge-to-precipitation ratio (GWR/P) (Adapted from CAVAZZANA, 2018).

\begin{tabular}{l|cc|c|c}
\hline Well & $\begin{array}{c}\boldsymbol{\Delta h} \\
(\mathbf{m})\end{array}$ & $\begin{array}{c}\boldsymbol{\Delta t} \\
\text { (days) }\end{array}$ & $\begin{array}{c}\text { GWR }(\mathbf{m m} \cdot \mathbf{y e a r}-\mathbf{1}) \\
\text { Symin }\end{array}$ & $\begin{array}{c}\text { GWR/P (\%) } \\
\text { Symin }\end{array}$ \\
\hline PO-01 & 2.73 & 356 & 280 & 19 \\
PO-03 & 1.22 & 182 & 245 & 16 \\
PO-04 & 1.93 & 336 & 210 & 14 \\
PO-05 & 0.96 & 76 & 461 & 31 \\
PO-06 & 1.37 & 106 & 472 & 32 \\
PO-07 & 1.37 & 215 & 233 & 16 \\
PO-08 & 3.23 & 161 & 732 & 49 \\
PO-09 & 0.90 & 76 & 432 & 29 \\
PO-10 & 0.71 & 91 & 285 & 19 \\
PO-11 & 0.72 & 91 & 289 & 19 \\
PO-14 & 1.15 & 130 & 323 & 22 \\
PO-16 & 1.90 & 194 & 357 & 24 \\
PO-18 & 2.49 & 131 & 694 & 47 \\
\hline Average & 1.59 & 165 & 386 & 26 \\
\hline
\end{tabular}

Symin $=0.100$ (Minimum Specific Capacity) (TAHAL; SANESUL, 1998)

GWR = groundwater recharge, in mm.year ${ }^{-1}$ (Mar 2015-Feb 2017)

GWR/P = groundwater recharge-to-precipitation ratio; considering 1,480 mm

NOTE: PO-08 (italics) not computed to calculate the means (well not drilled in the BAS).

The highest amplitudes for $\Delta \mathrm{h}$ and $\Delta \mathrm{t}$ coefficients correspond to measurements from wells deeper than $60 \mathrm{~m}$ (PO-01 and PO-04), reflecting the delay between precipitation and aquifer GWR. The PO-18 observation well (Figure 5), which has a SL depth below $9 \mathrm{~m}$, had an amplitude ( $\Delta \mathrm{h}$ ) above $2.4 \mathrm{~m}$ but for a shorter time compared to those of the wells with deeper SL. This may be due to its proximity to the surface water body, which causes the rapid discharge of the underground water storage, possibly causes the occurrence of sandier stratigraphy, and is aggravated by increased use of wells for permanent animal settlements. 
Figure 6 shows the spatial distribution of the GWR of Guariroba EPA (360 km²) estimated by the WTF method. the average GWR was $356 \mathrm{~mm} \cdot \mathrm{year}^{-1}$, which is equivalent to $24 \%$ of the precipitation.

\section{CONCLUSIONS AND RECOMMENDATIONS}

The results of this work show that the average underground water recharge value oscillates significantly, even in sedimentary and homogeneous aquifers such as the BAS. The WTF method was used to estimate underground water recharge values in the Guariroba river basin. The estimated average recharge value was $356 \mathrm{~mm} \cdot \mathrm{year}^{-}$ 1 and varied from 210-694 mm.year ${ }^{-1}$. Measurements were made at 13 different locations in the period March 2015-Feb 2017 and considering $1480 \mathrm{~mm}$ annual precipitation.

The estimated average recharge-to-precipitation ratio was $24 \%$ and varied from 14-47\%. Despite considering a lower value of the effective porosity parameter (Sy = 0.1) than the one suggested in the literature for the BAS, the estimated average recharge-to-precipitation ratio (24\%) was more than double that adopted by the state environmental agency for the BAS (10\%). This finding is important because the allocation of groundwater is based on the latter information. As the BAS is the hydrogeological unit with the largest outcropping area in Mato Grosso do Sul, it is recommended that these results be validated using other numerical models for estimating underground recharge and by installing infiltrometers to directly measure infiltration. 
Figure 6-Spatial distribution of the groundwater recharge of Guariroba EPA by the WTF method.

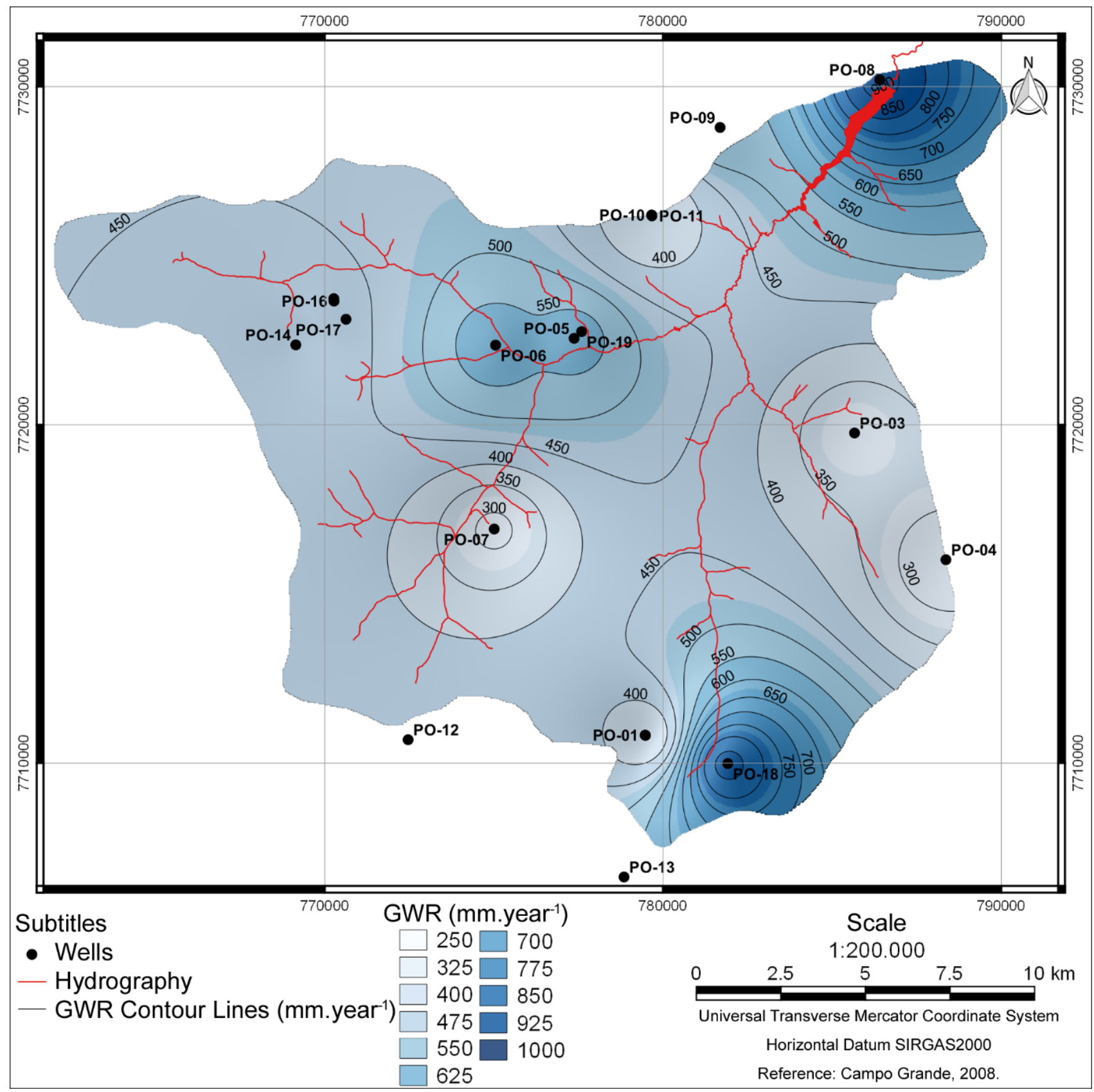

\section{ACKNOWLEDGEMENTS}

The authors are thankful for financial support from CNPQ Process No. 477667/2013-9, Universal Call Public Note - MCTI/CNPq No. 14/2013, and the Laboratory of Groundwater and Contaminated Areas - LASAC, UFMS. 


\section{REFERENCES}

CAMPO GRANDE. Plano de manejo da Área de Proteção Ambiental dos mananciais do córrego Guariroba (APA) do Guariroba. Campo Grande, 2008. 158 p.

CASADEI JM. Vulnerabilidade do aquífero livre na bacia hidrográfica do córrego Guariroba - Campo Grande, MS, em Programa PGTA [dissertation] Campo Grande: UFMS; 2016. 86 p.

CAVAZZANA GH. Relação entre a água superficial e a água subterrânea da Área de Proteção Ambiental do Guariroba, Estado de Mato Grosso do Sul, Brasil [PhD thesis]. Campo Grande: Programa PGTA/UFMS; 2018. 137 p.

CAVAZZANA GH, LASTORIA G, GABAS SG. Surface-groundwater interaction in unconfined sedimentary aquifer system in the Brazil's tropical wet region. Brazilian Journal of Water Resources 2019;24(8):2-15.

CHUNG IM, SOPHOCLEOUS MA, MITIKU DB, KIM NW. Estimating groundwater recharge in the humid and semi-arid African regions: review. Geosciences Journal 2016;20(5):731-744.

COMPANHIA DE PESQUISA DE RECURSOS MINERAIS-CPRM- SERVIÇO GEOLÓGICO DO BRASIL. Mapa Geológico do Estado de Mato Grosso do Sul (escala 1:1.000.000). São Paulo (Brazil): 2006.

LASTORIA G, GABAS SG, CAVAZZANA GH, CASADEI JM, AZOIA DE SOUZA T. Potencialidade dos recursos hídricos na bacia do córrego Guariroba, município de Campo Grande-MS. In: Geologia ambiental: tecnologias para o desenvolvimento sustentável. Org. por Cardozo, EL. Atena Editora, Ponta Grossa-PR; 2017. p. 204-213.

LASTORIA G, CAVAZZANA GH, OLIVA A, GABAS SG, CHANG HK. Contribuição da geofísica para a hidrogeologia da APA Guariroba, município de Campo Grande-MS. In: Anais do XX Congresso Brasileiro Águas Subterrâneas; nov./2018; Campinas-SP, Brazil. p. 38-41.

MANCUSO MA, CAMPOS JE. Aquífero Bauru. In: Mapa de águas subterrâneas do Estado de São Paulo (escala 1:1.000.000): nota explicativa. Coord. Rocha, G. DAEE, IPT, CPRM, São Paulo, 2005, p. 32-38.

SECRETARIA DE ESTADO DE MEIO AMBIENTE DO PLANEJAMENTO DA CIÊNCIA E TECNOLOGIA E INSTITUTO DE MEIO AMBIENTE DE MATO GROSSO DO SUL-SEMAC. Plano Estadual de Recursos Hídricos de Mato Grosso do Sul. Campo Grande- MS. Editora UEMS; 2010. 116 p.

TAHAL CONSULTING ENGINEERS LTD; EMPRESA DE SANEAMENTO DE MATO GROSSO DO SUL S.A.-SANESUL Estudos Hidrogeológicos de Mato Grosso do Sul.: Relatório Final. Campo Grande-MS, 1998, v.I, 398p. 